\title{
屋上緑化施設の公開，植栽形態ならびに費用に関する公共と民間の比較
}

\section{A Comparative Study on Open Use, Planting Form and Cost of the Roof-top Greening Facilities Installed on Public Buildings with Private Ones}

\author{
鈴木 弘孝* 金 甫炫** 藤田 茂 ${ }^{* * *}$ 加藤 真司 ${ }^{* * * *}$ \\ Hirotaka SUZUKI Bo Hyun KIM Shigeru FUJITA Masashi KATO
}

\begin{abstract}
This study was examined the planting forms and the actual condition of use on the roof-top buildings which was covered with greenery space more than $100 \mathrm{~m}^{2}$, extracting from the questionnaire that was intended for building owners. As a result, about a half of the buildings were opened and able to use, and private facilities have much higher rate of open facilities than public, but open areas were occupied about $80 \%$ by the public. It was supposed that the green area needs on planning and designing more than $1,000 \mathrm{~m}^{2}$ in order to open the roof-top greening facilities to the public. As a main use form, the garden use was the most many in both public and private, occupying about $50 \%$. The rate of planting tall trees and medium-height trees showed much higher in private facilities than in public, and the construction cost and maintenance cost were showed similar tendency, it was suggested that the level of construction and maintenance of the rooftop-greening showed marked differences between both facilities.
\end{abstract}

Keywords: rooftop-greening, open use, plants form, initial cost, running cost キーワード：屋上緑化, 公開, 植栽形態, 施工費, 維持管理費

\section{1. 研究の背景と目的}

近年，都市の周辺部に比して都市中心部の気温が上昇する「ヒ ートアイランド現象」が顕在化しており，地球温暖化防止対策と ともに都市のヒートアイランド対策の強力な推進が必要かつ急務 となっている。ヒートアイランド対策を推進するための地表面被 覆の改善策として, 国の施策 ${ }^{1)}$ 等において「屋上・壁面緑化の推 進」が位置づけられている。東京都では2001 年 4 月に条例を改正 し, 一定規模超の敷地面積を有寸る建築物の新築又は改築を行う 場合, 緑化可能な屋上部の面積の $20 \%$ 超の緑化を行うことを義 務づけた ${ }^{2)}$ 。これらの施策により, 屋上部の緑化面積は着実に増 大が図られている ${ }^{3)}$ 。建築物緑化に関寸るアンケート調査に基づ く先行研究例として, 小高ら ${ }^{4)}$ は, 屋上開発研究会が実施したア ンケート調査 ${ }^{5)}$ の結果に基づき，地方行政担当者の屋上緑化に対 する認識について解析した。鹿土ら ${ }^{6}$ は，渋谷区・新宿区に関し て屋上緑化施設の分布傾向を調べ, 屋上緑化施設は中低層の建築 物に多いことを明らかにしている。佐久間ら ${ }^{7)}$ は, 壁面緑化資材 会社等 45 社を対象としてアンケート調査を行い, 緑化の目的, 緑 化の手法，使用した植物の種類等について整理している。武藤ら ${ }^{8)}$ は建築や緑化に関連した仕事に従事していない被験者を対象に, 壁面緑化に関する評価構造を把握するために評価グリッドを用い たヒアリング調査を実施し, 壁面緑化計画上の課題を整理してい る。鈴木ら ${ }^{9)}$ は, 屋上緑化に従事する民間企業等を対象としてア ンケート調査を行い, 壁面緑化の市場性や技術的な課題等につい て検討した。一方，屋上緑化技術に関して，藤田ら ${ }^{10)}$ は，高木・ 中木から宿根草を導入した多用な工法・資材を用いた屋上庭園技 術の事例を報告している。広永ら ${ }^{11)}$ は, 20 種類の植物を用いて土 層軽量化と省力管理に向けたヤシ繊維製土のうによる屋上緑化技 術を報告している。木野村ら ${ }^{12)}$ は, オフィスワーカーを対象とし て緑化された屋上の休憩機能としての機能を評価している。

一方, 鈴木ら ${ }^{13)}$ は, 都市住民の利用に着目してアンケート調査 の結果から, 屋上緑化施設の公開の実態を整理し, 調査対象とし
た建物の約半数が公開していたことを報告している。今後，屋上 緑化技術を都市市街地において，さらに普及・発展させていくた めには，ヒートアイランド対策等都市環境の改善を図る上で緑化 施設の内容や維持管理の状態等についても検討を行い，都市の緑 とオープンスペースのネットワークを形成していく上での拠点と して適切に評価していくことが必要と考えられる。

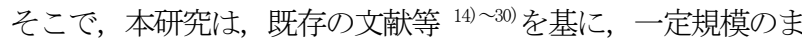
とまりのある屋上緑化を行っている建築物を対象として行ったア ンケート調査の結果から，公共施設と民間施設との比較検討によ り屋上緑化施設の公開，植栽形態と費用の実態について明らかに することを目的とする。

\section{2. 研究の方法}

今回のアンケート調査では, 屋上緑化を行っている建築物で, 緑化面積が $100 \mathrm{~m}^{2}$ 超の建築物について，既往の文献等 407 件を調 查対象とした。このうち, 公共建築は 119, 民間建築は 288 であ った。調査票の配布期間は，2008 年 1 月 18 日より 3 月 7 日まで 実施した。アンケート調査の実施概要は表一 1 に示すとおりであ り，有効回答数は全体で 99 , 有効回答率は $24.3 \%$ \%゙った。こ のうち, 公共建築からは 46 (有効回答率 $38.7 \%$ ), 民間建築から は53（有効回答率 18.4\%) であった。なお，マンション等の住宅 施設については，調査対象が屋上緑化の規模を $100 \mathrm{~m}^{2}$ 超とし，施 設の公開による利用状況の把握に重点を置いたことから調査の対 象外とした。集計にはSSRI WASS 即析集計クエリーver2. 0 を用い た。アンケート調査に用いた質問項目は，表一 2 に示すとおりで ある。なお，本稿で扱う「利用」とは，整備された屋上緑化施設 について，施設内に立ち入り，植物や庭園の観賞，散策，休息等 に供する行為を総称した概念として定義する。また，「公開」とは 建築居住者や勤務者以外の第三者が屋上緑化施設を利用できる状 態を言う。

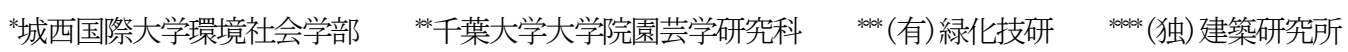


表一1 アンケート調査項目

\begin{tabular}{|c|c|c|c|}
\hline 調査日 & 2008.1 .18 & -3.7 & \\
\hline （1）公共建築計 & $\begin{array}{r}\text { 配布数: } \\
119\end{array}$ & $\begin{array}{r}\text { 有効回答数： } \\
46\end{array}$ & $\begin{array}{c}\text { 有効回答率 : } \\
38.7 \%\end{array}$ \\
\hline （2） 民間建築計 & $\begin{array}{r}\text { 配布数 : } \\
288 \\
\end{array}$ & $\begin{array}{r}\text { 有効回答数 : } \\
53 \\
\end{array}$ & $\begin{array}{c}\text { 有効回答率： } \\
18.4 \% \\
\end{array}$ \\
\hline 合計 & $\begin{array}{r}\text { 配布数 : } \\
407 \\
\end{array}$ & $\begin{array}{r}\text { 有効回答数 : } \\
\qquad 99\end{array}$ & $\begin{array}{c}\text { 有効回答率 : } \\
24.3 \% \\
\end{array}$ \\
\hline 配布 - 回答方法 & \multicolumn{3}{|l|}{ 郵送 } \\
\hline
\end{tabular}

\section{3. 結果}

\section{(1) 建築物の用途}

図一 1 に今回の調查対象とした屋上緑化施設の建築用途を示 す。公共施設では官公庁施設が $58.7 \%$ と全体の $1 / 2$ 以上を占め, 次いで学校とその他が $13.0 \%$, 工場が $6.5 \%$ となってた。工場 には，廃棄物処分場等が含まれている。一方，民間施設では，事 務所が $35.8 \%$ と全体の約 $1 / 3$ を占め, 次いで店舗・商業施設が $24.5 \%$ ，学校が $17.0 \%$ の順となっていた。これより，官公庁施設 は公共の建築物が主体となっているのに対して，事務所と店舗・ 商業施設は民間主体となっていた。学校，病院については公共よ りも民間の比率が高くなっていた。

\section{（2）屋上緑化の緑化面積と公開の状況}

調査原票から公開している建築物の緑化面積を集計した結果 は, 表一 3 のとおりである。これより, 調査対象の建築件数で見 ると，公開している建築物が 65 件，非公開の建築物が 34 件とな っており, 約 6 割の建築物が公開されていた。公開されている建 築物の内訳として，公共の建築物が 28 件，民間の建築物が 37 件 であり，公開割合の比率では公共，民間とも約 6 割の施設で公開 されていた。また, 整備された屋上緑化面積は全体で 202, $921 \mathrm{~m}^{2}$ であり，このうち公開されている緑化施設面積は $174,921 \mathrm{~m}^{2}$ と全 体の 8 割強を占めた。公開されている緑化施設面積では, 公共建 築が $135,938 \mathrm{~m}^{2}$ と公開面積全体の約 9 割を占めていた。平均面積 で見ると公開されている施設では公共建築が $4,855 \mathrm{~m}^{2}$, 民間建築 が 1, $054 \mathrm{~m}^{2}$ となり，両者の間には大きな差が見られた。

さらに，公開の時間についての制限があるかについて，尋ねた 結果は図ー 2 に示寸とおりである。公共と民間の別に見ると, 公 共施設では, 「日中のみ」と制限している施設が $71.4 \%$ を示した のに対して，民間施設では 50.0\%となっており，「日中のみ」の 制限は公共施設が民間施設を上回る一方，「制限していない施設 については, 公共施設が $21.4 \%$ に対して, 民間施設が $50.0 \%$ 示 し，民間が公共を大きく上回っており，両者の間には $\chi^{2}$ 検定で有 意な差が認められた $(\mathrm{p}<0.05)$ 。

また，屋上緑化されている建物の階数について回答よりまとめ ると, 表一 4 に示寸とおりである。屋上緑化が複数階に及んだ事 例も含まれているため, 回答数には複数回答を含んでいる。これ より，公共施設では全体の 8 割超が 5 階以下の中低層部であり, 同じく民間施設では約 6 割が中低層部となっており，いずれも中 低層部の緑化の割合は高いものの，公共の方が中低層部の占める 割合は高かった。なお, 低層, 中層, 高層の分類は長寿社会対応 住宅設計指針 ${ }^{32}$ をもとに行った。

\section{（3）屋上緑化の施設形態と植栽形態}

屋上緑化の施設形態をまとめると図一 3 に示すとおり，公共施 設では，「庭園」が56.6\%で最も多く，次いで「芝生」 $26.1 \%$ ，「コ ケ・セダム類」 $13.0 \%$ と続いている。これに対して, 民間施設では, 「庭園」が $47.8 \%$ ，「芝生」 $26.1 \%$ に次いで「花壇」が $11.3 \%$ と なっていた。これより，いずれの場合も約半数の建築物では，庭 園として整備されていたことから，屋上緑化の施設形態として， 観賞や散策等の利用が図られる施設として屋上が緑化されていた。
表ー2 アンケート調査の概要

\begin{tabular}{|c|c|}
\hline 区分 & 質問項目 ・ 関連項目 \\
\hline $\begin{array}{l}\text { 1. 屋上緑化への取 } \\
\text { り組み }\end{array}$ & $\begin{array}{l}\text { 問 } 1 \text { 建築物の用途 } \\
\text { 問 } 2 \text { 屋上緑化の動機 } \\
\text { 問 } 3 \text { 屋上緑化の目的 (M. A.) } \\
\text { 問 } 4 \text { 屋上緑化した効果の度合 }\end{array}$ \\
\hline $\begin{array}{l}\text { 2. 緑化形態・植物 } \\
\text { 形態 }\end{array}$ & $\begin{array}{ll}\text { 問 } 5 & \text { 屋上緑化の主な形態 } \\
\text { 問 } 6 & \text { 屋上緑化植物の形態 (植物名はF.A.) }\end{array}$ \\
\hline 3. 緑化施設 & $\begin{array}{ll}\text { 問 } 7 & \text { 屋上緑化施設の重量 } \\
\text { 問 } 8 & \text { 屋上緑化の土壌厚 } \\
\text { 問 } 9 & \text { 灌水装置の有無・種類 } \\
\end{array}$ \\
\hline 4. 屋上緑化の利用 & 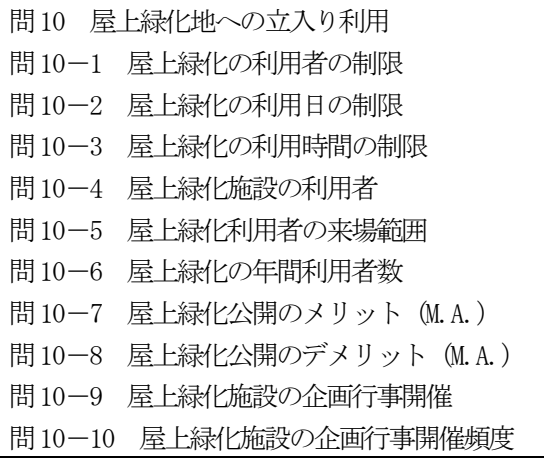 \\
\hline 5. 屋上緑化の助成 & $\begin{array}{l}\text { 問 } 11 \text { 屋上緑化の行政からの助成·優遇措置 } \\
\text { 問 } 11-1 \text { 屋上緑化の行政からの助成·優遇措置 } \\
\text { (M. A. ) }\end{array}$ \\
\hline 6. 屋上緑化の費用 & $\begin{array}{ll}\text { 問 } 12 & \text { 屋上緑化の施工費 } \\
\text { 問 } 13 & \text { 屋上緑化の維持管理費 } \\
\end{array}$ \\
\hline $\begin{array}{l}\text { 7. 屋上緑化の維持 } \\
\text { 管理 }\end{array}$ & $\begin{array}{ll}\text { 問 } 14 & \text { 屋上緑化の維持管理作業項目（M. A.） } \\
\text { 問 } 15 & \text { 屋上緑化の維持管理作業委託状況 } \\
\text { 問 } 16 & \text { 屋上緑化のコスト高維持管理作業項目 } \\
\text { 問 } 17 & \text { 屋上緑化の維持管理上の問題点 (M. A. ) } \\
\end{array}$ \\
\hline 8. 屋上緑化の要望 & $\begin{array}{ll}\text { 問 } 18 \text { 屋上緑化の存続希望年数 } \\
\text { 問 } 19 \text { 屋上緑化具体化上の考慮点 (M. A.) } \\
\text { 問 } 20 & \text { 屋上緑化の行政に対する要望 (M. A.) } \\
\end{array}$ \\
\hline 9. その他 & 問 21 屋上緑化普及に対寸る意見（F.A.） \\
\hline
\end{tabular}

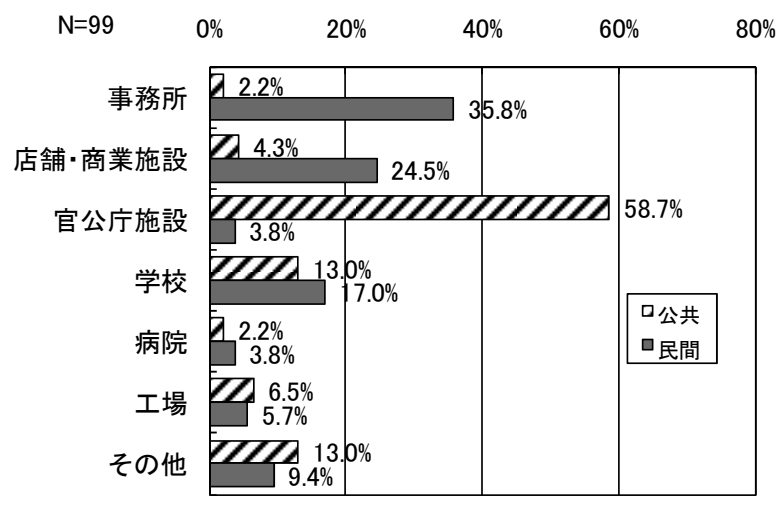

図-1 対象建築物の用途

公共と民間の間では有意な差は見られなかったが, 庭園, 菜園, 花壇では民間の方が公共よりも上回っていたのに対して，芝生， コケ・セダム類では公共の方が民間を上回る傾向が見られた。 次に, 屋上緑化の植栽形態についてみると, 図一 4 に示寸とおり, 公共施設では，「低木」が 33, 7\% で約 1/3 を占め，次いで「芝生 類」が $23.5 \%$ ，「中木」が $16.3 \%$ ，八ーブ等の「草本類」が $12.2 \%$ 
表一3 緑化施設面積の内訳 ${ }^{31)}$

\begin{tabular}{c|c|r|r|r}
\hline \multicolumn{2}{c|}{ 区分 } & \multicolumn{1}{|c|}{ 公開 } & \multicolumn{1}{c}{ 非公開 } & \multicolumn{1}{c}{ 計 } \\
\hline 公共 & 件数 & 28 & 18 & 46 \\
& 計 & $135,938 \mathrm{~m}^{2}$ & $15,798 \mathrm{~m}^{2}$ & $151,736 \mathrm{~m}^{2}$ \\
& 平均 & $4,855 \mathrm{~m}^{2}$ & $878 \mathrm{~m}^{2}$ & $3,299 \mathrm{~m}^{2}$ \\
\hline 民間 & 件数 & 37 & 16 & 53 \\
& 計 & $38,983 \mathrm{~m}^{2}$ & $12,202 \mathrm{~m}^{2}$ & $51,185 \mathrm{~m}^{2}$ \\
& 平均 & $1,054 \mathrm{~m}^{2}$ & $763 \mathrm{~m}^{2}$ & $966 \mathrm{~m}^{2}$ \\
\hline \multirow{2}{*}{ 合計 } & 件数 & 65 & 34 & 99 \\
& 計 & $174,921 \mathrm{~m}^{2}$ & $28,000 \mathrm{~m}^{2}$ & $202,921 \mathrm{~m}^{2}$ \\
& 平均 & $2,651 \mathrm{~m}^{2}$ & $824 \mathrm{~m}^{2}$ & $2,050 \mathrm{~m}^{2}$ \\
\hline
\end{tabular}

$\begin{array}{llllll}\mathrm{N}=64 & 0 \% & 20 \% & 40 \% & 60 \% & 80 \%\end{array}$

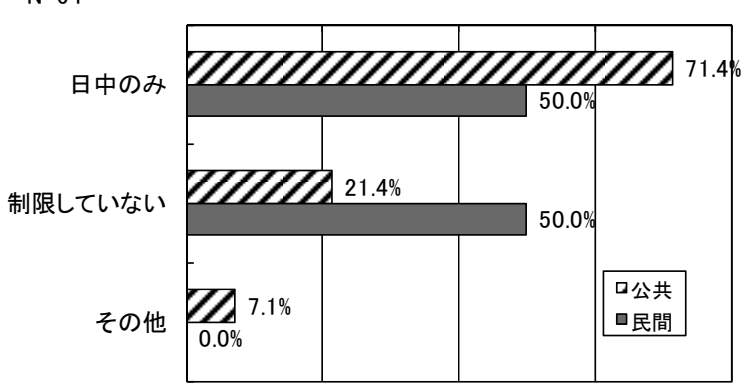

図一2 屋上緑化の利用制限

表一4 緑化された建物の階数

\begin{tabular}{l|r|r}
\hline \multicolumn{1}{c|}{ 区分 } & 公共 & 民間 \\
\hline 低層(1 階 2 階以下) & $24(48.0 \%)$ & $18(26.5 \%)$ \\
中層(3 階～5 階以下) & $19(38.0 \%)$ & $24(35.3 \%)$ \\
高層(6 階超) & $7(14.0 \%)$ & $26(38.2 \%)$ \\
\hline
\end{tabular}

の順であった。一方，民間施設においては，「低木」が $28.0 \%$, 次いで「中木」 $21.2 \%$ ，「芝生類」 $17.4 \%$ の順となっていた。これ より，低木や芝生，セダム等の植物では公共の方が民間を大きく 上回っていたのに対して, 高木や中木の樹木植栽, ハーブ等の草 本類は民間の方が上回る傾向が見られた。ここで,樹木の区分は,

「道路緑化技術基準・同解説」 ${ }^{33}$, 日本道路協会(1988) の基準を 参考として, 高木は $3 \mathrm{~m}$ 以上の樹木, 中木は $1 \mathrm{~m}$ 以上 $3 \mathrm{~m}$ 未満, 低 木は $1 \mathrm{~m}$ 未満とした。

また，各々の屋上に植栽されている主な植物を多い順に上位三 位までを記述してもらい，各順位毎に回答数 2 以上の植物を植栽 区分別，使用頻度別にまとめると表一 5 のとおりであった。これ より，一位順位の中では，コウライシバ(13 件)，ノシバ (5 件) の芝生類 (合計 18 件) の使用頻度が高く, 次いでツツジ類 (3 件), サツキツツジ(2 件), アベリア (2 件), アセビ（2 件)等の低木(合 計 11 件)が多く使用されていた。また，二位順位では，ローズマ リー (5 件), ラベンダー (3 件), ヤブラン (3 件) 等の草本類(合計 13 件) の使用頻度が高く, 次いでツツジ(4 件), イヌツゲ (3 件) の低木 (合計 7 件) が使用されていた。これに対して三位順位にな ると, オリーブ(3 件), モミジ(3 件), コナラ (2 件), ヒメユズ リ八 ( 2 件)等の高木 (合計 10 件)の使用頻度が高くなっていた。こ れらの植栽種については, アンケート調査の回答結果によるもの であり, 回答者の植物に対する知識の差異により影響を受けるた め, 使用されている植栽種の実情については, 実測調査を行う等 によりさらに検討を行うことが必要と考えられる。

\section{（4）屋上緑化の土層厚}

屋上緑化施設の植栽基盤となる土層の厚さは，図一 5 に示すと おり, 公共施設では「 $20 \mathrm{~cm}$ 超〜 $50 \mathrm{~cm}$ 以下」が $50.0 \%$ と全体の $1 / 2$

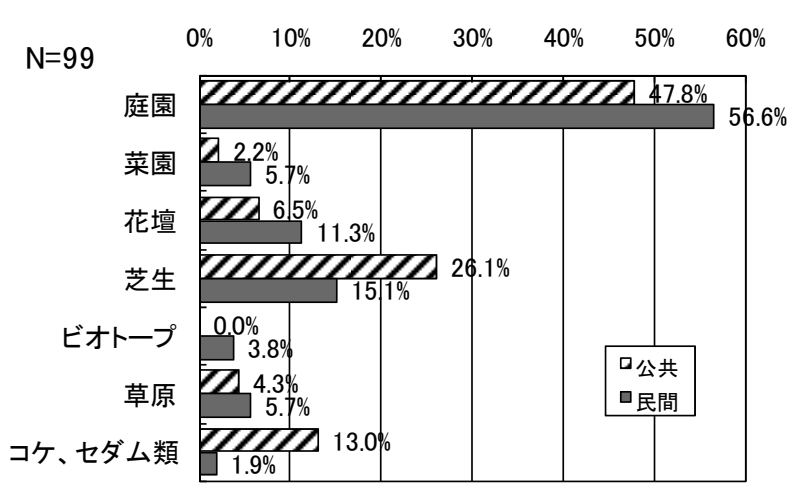

図-3 屋上緑化の施設形態

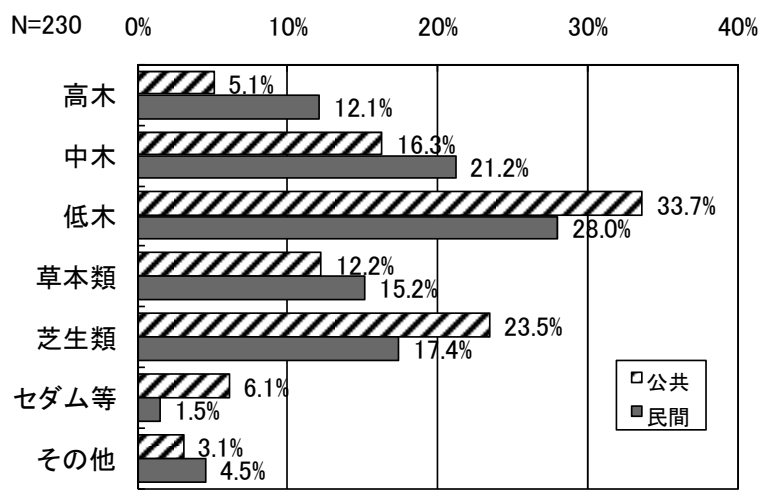

図-4 屋上緑化の植栽形態

を占め, 次いで, 「10cm 超〜 $20 \mathrm{~cm}$ 以下」が $21.4 \%$,「5 cm 超 $10 \mathrm{~cm}$ 以下」が $11.9 \%$ の順であった。これに対して, 民間施設では「 $20 \mathrm{~cm}$ 超〜 $50 \mathrm{~cm}$ 以下」が $45.3 \%$,「50cm 超〜 $100 \mathrm{~cm}$ 以下」が $17.0 \%$,「10cm 超〜 $20 \mathrm{~cm}$ 以下」と $\lceil 5 \mathrm{~cm}$ 超〜 $10 \mathrm{~cm}$ 以下」が $15.1 \%$ の順となって いた。民間施設では「 $5 \mathrm{~cm}$ 以下」の土層厚は見られなかったのに 対して，「50cm 超〜 $100 \mathrm{~cm}$ 以下」では民間施設が $17.0 \%$ を示して 公共施設の $2.4 \%$ をきく上回っており，民間施設の方が公共施 設よりも土層厚の厚い大きい施設が多い傾向が見られた。このこ とは, 高木・中木を植栽する屋上施設についての土層厚分布を示 した表一 6 から見られるとおり, 土層厚 $50 \mathrm{~cm}$ 超では, 高木・中木 の植栽本数が民間施設の方が多いことによると考えられる。

\section{（5）屋上緑化施設の耐荷重量}

屋上緑化施設の耐荷重量は，図一6に示す。ここで，耐荷重量 の区分として，荷重の分類は，建築基淮法施行令第 85 条で定め られている「屋上広場・バルコニーの積載荷重」を参考とした。 これより，公共施設では「300 kg/ $\mathrm{m}^{2}$ 超〜 $500 \mathrm{~kg} / \mathrm{m}^{2}$ 以下」が $28.6 \%$ と最も高く, 次いで「60kg/m² $\mathrm{m}^{2}$ 以下」, 「240 kg/m超〜 $300 \mathrm{~kg} / \mathrm{m}^{2}$ 以下」, 「500kg/m超〜」がとも に $11.9 \%$ と続いている。一方，民間施設では，「240 kg/m超〜 $300 \mathrm{~kg} / \mathrm{m}^{2}$ 以下」が $34.0 \%$ と最も多く，次いで「 $60 \mathrm{~kg} / \mathrm{m}^{2}$ 以下」と

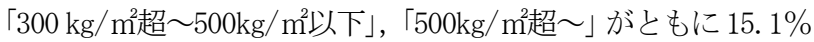
となっていた。これより, $180 \mathrm{~kg} / \mathrm{m}^{2}$ 以下では両者の傾向に大差は 見られないが, 「180 kg/m超〜 $240 \mathrm{~kg} / \mathrm{m}^{2}$ 以下」と「300kg/m超〜 $500 \mathrm{~kg} / \mathrm{m}^{2}$ 以下」では公共が民間を大きく上回ったのに対して， $\left\lceil 240 \mathrm{~kg} / \mathrm{m}^{2}\right.$ 超〜 $300 \mathrm{~kg} / \mathrm{m}^{2}$ 以下」では民間が公共を大きく上回って いた。民間施設では 240〜 $300 \mathrm{~kg} / \mathrm{m}^{2} か ゙$ 最も高い割合を占めており, 公共では 300 $500 \mathrm{~kg} / \mathrm{m}^{2}$ の割合が最も高い割合を占め，公共施設 の方が民間施設よりも植栽基盤となる土壌や植物を積載した重量 の大きい施設が多い傾向が見られた $(p<0.1)$ 。 
表ー5 屋上緑化に使用された主な植物種

\begin{tabular}{|c|c|c|c|c|c|c|}
\hline \multirow{2}{*}{$\begin{array}{l}\text { 植栽 } \\
\text { 区分 }\end{array}$} & \multicolumn{2}{|l|}{ 一位順位 } & \multicolumn{2}{|l|}{ 二位順位 } & \multicolumn{2}{|l|}{ 三位順位 } \\
\hline & 種名 & 件 & 種名 & 件 & 種名 & 件 \\
\hline \multirow{5}{*}{ 高木 } & クスノキ & 2 & オリーブ & 2 & オリーブ & 3 \\
\hline & シマトネリコ & 2 & & & モミジ & 3 \\
\hline & & & & & コナラ & 2 \\
\hline & & & & & ヒメユズリハ & 2 \\
\hline & 計 & 4 & 計 & 2 & 計 & 10 \\
\hline \multirow[t]{4}{*}{ 中木 } & マサキ & 2 & & & & \\
\hline & ブルーベリー & 2 & & & & \\
\hline & ソヨゴ & 2 & & & & \\
\hline & 計 & 6 & 計 & & 計 & \\
\hline \multirow[t]{6}{*}{ 低木 } & ツツジ類 & 3 & ツツジ類 & 4 & アジサイ & 2 \\
\hline & サツキツツジ & 2 & イヌツゲ & 3 & バラ & 2 \\
\hline & アベリア類 & 2 & & & & \\
\hline & アセビ & 2 & & & & \\
\hline & クチナシ & 2 & & & & \\
\hline & 計 & 11 & 計 & 7 & 計 & 4 \\
\hline \multirow{5}{*}{$\begin{array}{l}\text { 草本 } \\
\text { 類 }\end{array}$} & タイム類 & 4 & ローズマリー & 5 & & \\
\hline & タマリュウ & 2 & ラベンダー & 3 & & \\
\hline & シバザクラ & 2 & ヤブラン & 3 & & \\
\hline & & & ヘデラ類 & 2 & & \\
\hline & 計 & 8 & 計 & 13 & 計 & \\
\hline \multirow[t]{3}{*}{ 芝類 } & コウライシバ & 13 & コウライシバ & 4 & ノシバ類 & 2 \\
\hline & ハシバ類 & 5 & & & & \\
\hline & 計 & 18 & 計 & 4 & 計 & 2 \\
\hline \multirow{2}{*}{$\begin{array}{l}\text { セダ } \\
\text { ム等 }\end{array}$} & セダム類 & 2 & & & & \\
\hline & 計 & 2 & 計 & & 計 & \\
\hline
\end{tabular}

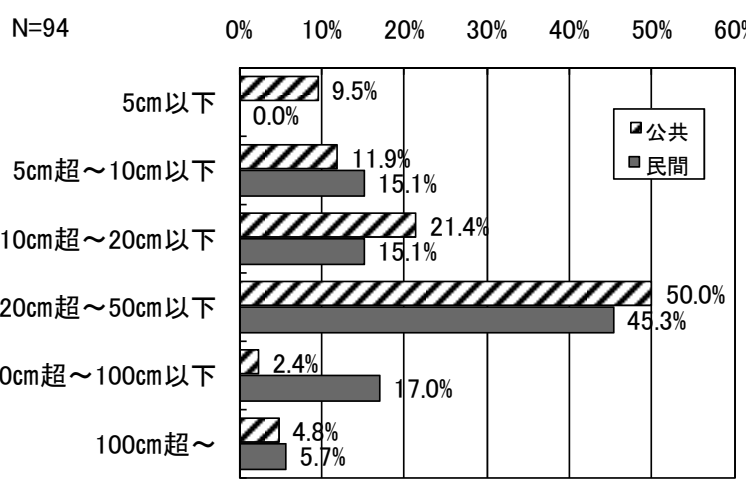

図-5 屋上緑化の土層厚

表一6 樹木植栽の形態と土層厚

\begin{tabular}{l|r|r|r|r|r|r}
\hline \multirow{2}{*}{ 土層厚 } & \multicolumn{3}{|c|}{ 公共施設 } & \multicolumn{3}{|c}{ 民間施設 } \\
\cline { 2 - 7 } & 高木 & 中木 & 低木 & 高木 & 中木 & 低木 \\
\hline $5 \mathrm{~cm}$ 以下 & 0 & 0 & 0 & 0 & 0 & 0 \\
$5 \mathrm{~cm}$ 超 $10 \mathrm{~cm}$ 以下 & 0 & 1 & 1 & 0 & 1 & 2 \\
$10 \mathrm{~cm}$ 超 $20 \mathrm{~cm}$ 以下 & 0 & 3 & 7 & 0 & 4 & 3 \\
$20 \mathrm{~cm}$ 超 $\sim 50 \mathrm{~cm}$ 以下 & 3 & 10 & 18 & 6 & 14 & 20 \\
$50 \mathrm{~cm}$ 超 $100 \mathrm{~cm}$ 以下 & 1 & 0 & 1 & 7 & 6 & 7 \\
$100 \mathrm{~cm}$ 超 & 1 & 1 & 2 & 3 & 3 & 5 \\
\hline \multicolumn{2}{l}{}
\end{tabular}

このことから，耐荷重量では公共施設の方が民間施設よりも大 きく, 強固な構造となっていることが窺える。植栽構造は民間の 方が樹木の割合が高い傾向であることを勘案すると, 公共では植 栽形態に比して, より許容量の大きい建築物構造となっている傾

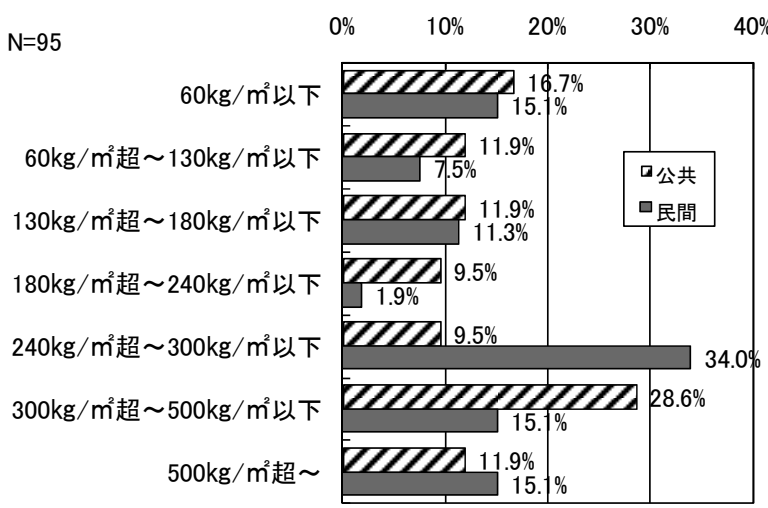

図-6＼cjkstart屋上緑化施設の耐荷重量

向が見られた。

\section{（6）屋上緑化の施工費}

屋上緑化の施工費については，図一7 (無回答を除く)に示すと おり，公共施設では屋上緑化施設 $1 \mathrm{~m}^{2}$ 当りの単価で，「2 万円超〜 5 万円 $/ \mathrm{m}^{2}$ 以下」が $31.6 \%$ と最も多く, 次いで「 1 万円超〜 2 万円 $/$ $\mathrm{m}^{2}$ 以下」が $26.3 \%$ ，「 1 万円以下」と「5 万円超〜 10 万円以下」が 15.8\%の順となっていた。これに対して，民間施設では，「2 万円 超〜 5 万円 $/ \mathrm{m}^{2}$ 以下」と「10 万円 $/ \mathrm{m}^{2}$ 超〜」が $28.6 \%$ と最も多く, 次いで「5 万円超〜 10 万円 $/ \mathrm{m}^{2}$ 以下」が $23.8 \%$ となっていた。公 共と民間の別では, 両者の間に有意な差は認められないものの, 2 万円以下では公共の方が民間を上回っているのに対して，5 万円 超では民間の方が公共よりも大きく上回っており，10 万円超では その差がさらに大きくなる傾向が見られた。

表一 5 に示す植栽区分のうち高木・中木を植栽していた建築物 について，施工費，維持管理費の各々の構成をまとめると表一 7 に示寸とおり，施工費については ${ }^{2}$ 当たりの単価が 5 万円超の建 築物が半数超を占めている。さらに，このうちショッピングモー ルやホテル等の集客性の高い民間施設についてみると，表一8に 示すとおり約 7 割が 5 万円超であり，2 万円以下は見られなかっ た。以上により，今回調査対象とした建築物において整備された 緑化施設について，民間施設の方が公共施設よりも緑化された施 設への投資額は大きく，これは緑化施設の植栽形態として公共施 設よりも高木・中木の樹木をより多く植栽する傾向を反映してい ると考えられる。

\section{（7）屋上緑化の維持管理費}

屋上緑化施設 $1 \mathrm{~m}^{2}$ 当りの管理費単価について, 図一8 (無回答を 除く)に示すとおり，公共施設では「1千円/ $\mathrm{m}^{2}$ 以下」が $67.6 \%$ と 最も多く，次いで「 1 千円 $/ \mathrm{m}^{2}$ 超〜 2 千円 $/ \mathrm{m}^{2}$ 以下」と「2 千円 $/ \mathrm{m}^{2}$ 超〜 5 千円 $/ \mathrm{m}^{2}$ 以下」が共に $14.7 \%$ となり, 維持管理に要するコス

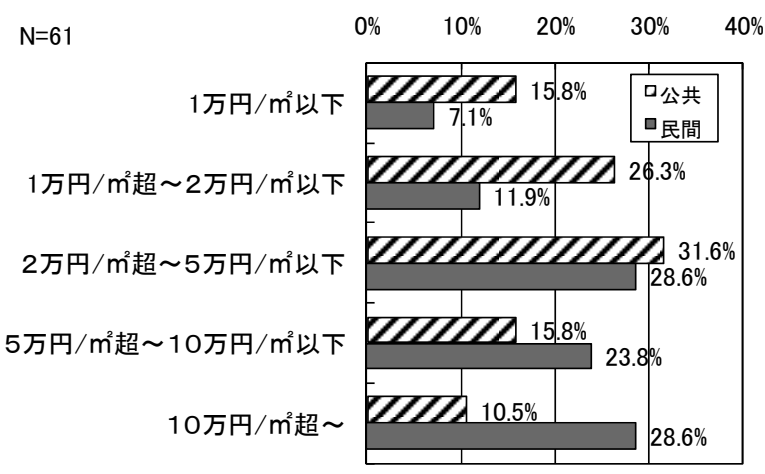

図-7 屋上緑化の施工費 
表－7 高木・中木を主体とした屋上施設

\begin{tabular}{|c|c|c|c|}
\hline \multicolumn{2}{|l|}{ 施工費 } & \multicolumn{2}{|l|}{ 維持管理費 } \\
\hline 区分 & $\begin{array}{l}\text { 施 } \\
\text { 設 } \\
\text { 数 }\end{array}$ & 区分 & $\begin{array}{l}\text { 施 } \\
\text { 設 } \\
\text { 数 }\end{array}$ \\
\hline 1 万円 $/ \mathrm{m}^{2}$ 以下 & 1 & 1 千円 $/ \mathrm{m}^{2}$ 以下 & 2 \\
\hline 1 万円 $/ \mathrm{m}^{2}$ 超 2 万円 $/ \mathrm{m}^{2}$ 以下 & 2 & 1 千円/m超〜2 千円/m²以下 & 1 \\
\hline 2 万円 $/ \mathrm{m}^{2}$ 超 $~ 5$ 万円 $/ \mathrm{m}^{2}$ 以下 & 2 & 2 千円 $/ \mathrm{m}^{2}$ 超 5 千円 $/ \mathrm{m}^{2}$ 以下 & 4 \\
\hline 5 万円 $/ \mathrm{m}^{2}$ 超 10 万円 $/ \mathrm{m}^{2}$ 以下 & 4 & 5 千円 $/ \mathrm{m}^{2}$ 超 10 千円 $/ \mathrm{m}^{2}$ 以下 & 3 \\
\hline 10 万円 $/ \mathrm{m}^{2}$ 超〜 & 3 & 10 千円 $/ \mathrm{m}^{2}$ 超 & 2 \\
\hline
\end{tabular}

表－8 百貨店・ホテルの施工費と維持管理費

\begin{tabular}{|c|c|c|c|}
\hline \multicolumn{2}{|l|}{ 施工費 } & \multicolumn{2}{|l|}{ 維持管理費 } \\
\hline 区分 & $\begin{array}{l}\text { 施 } \\
\text { 設 } \\
\text { 数 }\end{array}$ & 区分 & $\begin{array}{l}\text { 施 } \\
\text { 設 } \\
\text { 数 }\end{array}$ \\
\hline 1 万円 $/ \mathrm{m}^{2}$ 以下 & 0 & 1 千円 $/ \mathrm{m}^{2}$ 以下 & 0 \\
\hline 1 万円 $/ \mathrm{m}^{2}$ 超 2 万円 $/ \mathrm{m}^{2}$ 以下 & 0 & 1 千円/m超〜2 千円/ $\mathrm{m}^{2}$ 以下 & 0 \\
\hline 2 万円/m超〜 5 万円/m²以下 & 2 & 2 千円/m超〜5 千円/的以下 & 3 \\
\hline 5 万円 $/ \mathrm{m}^{2}$ 超 $\sim 10$ 万円 $/ \mathrm{m}^{2}$ 以下 & 3 & 5 千円 $/ \mathrm{m}^{2}$ 超 10 千円 $/ \mathrm{m}^{2}$ 以下 & 2 \\
\hline 10 万円 $/ \mathrm{m}^{2}$ 超〜 & 2 & 10 千円 $/ \mathrm{m}^{2}$ 超 & 2 \\
\hline
\end{tabular}

卜は 5 千円 $/ \mathrm{m}^{2}$ 以下の建築物が全体の $97 \%$ 占めた。これに対して， 民間施設では「1 千円 $/ \mathrm{m}^{2}$ 超〜 2 千円 $/ \mathrm{m}^{2}$ 以下」と「2 千円 $/ \mathrm{m}^{2}$ 超〜 5 千円 $/ \mathrm{m}^{2}$ 以下」が共に $26.3 \%$ を示し, 次いで, 「1千円 $/ \mathrm{m}^{2}$ 以下」 が $21.1 \%$ となっていた。公共では 1 千円 $/ \mathrm{m}^{2}$ 以下の維持管理費が 全体の約 7 割を占め, 民間より割合が高く, その差も顕著であり, 両者の間には $\chi^{2}$ 検定で有意な差が認められた $(\mathrm{p}<0.01)$ 。

一方，民間では 1 千円から 5 千円 $/ \mathrm{m}^{2}$ 以下の範囲が約半数を占 めた。高木・中木を植栽した建築物について, 維持管理費の構成 をまとめると表一 7 に示すとおり, $\mathrm{m}^{2}$ 当たりの単価が 2 千円超の 建築物が 7 割超を占めていた。さらに，ショッピングモールやホ テル等の集客性の高い民間施設についてみると，表一8に示すと おり約 6 割が 5 千円超であり，2 千円以下は見られなかった。維 持管理費に 5 千円/ $\mathrm{m}^{2}$ 超をかけている公共施設はほとんど見られ ないことから，緑化施設の維持管理に係るコストについても民間 施設の方が公共施設よりもコストをかけて緑化施設を維持してい る傾向が見られる。

\section{4. 考察}

アンケート調査の結果から, 屋上緑化の公開と整備された緑化 施設の植栽形態，建設及び維持管理に要する費用等の実態につい て，公共施設と民間施設の比較検討を行った。

整備された緑化施設の公開の状況として, 調査対象とした緑化 施設面積の約 8 割を公共施設が占め, 1 件当たりの平均面積も公 共が約 4, $824 \mathrm{~m}^{2} /$ 件で, 民間の約 4.6 倍の大きさを示し, 公開され た緑化面積の平均はいずれも $1,000 \mathrm{~m}^{2} /$ 件を上回っている。これに 対して, 非公開の屋上緑化施設では, 公共・民間とも平均面積 $1,000 \mathrm{~m}^{2} /$ 件以下となっており, 緑化施設を公開寸るための必要面 積規模としては緑化面積が $1,000 \mathrm{~m}^{2}$ 上回ることが計画・設計上 の目安となることが示唆された。

屋上緑化施設の公開時間については，屋上への立ち入りを夜間 制限している比率が，公共の方が民間を大きく上回っていた。鹿 土ら ${ }^{4)}$ は東京都新宿区と渋谷区を対象に屋上緑化施設の分布傾向 を調べた結果から, 屋上緑化施設はどの建物用途においても中低 層の建物が多いことを報告している。今回の調査結果からは, 公 共，民間とも中低層部の緑化の割合は高いものの，公共の方が中 低層部の占める割合は高い傾向が見られた。

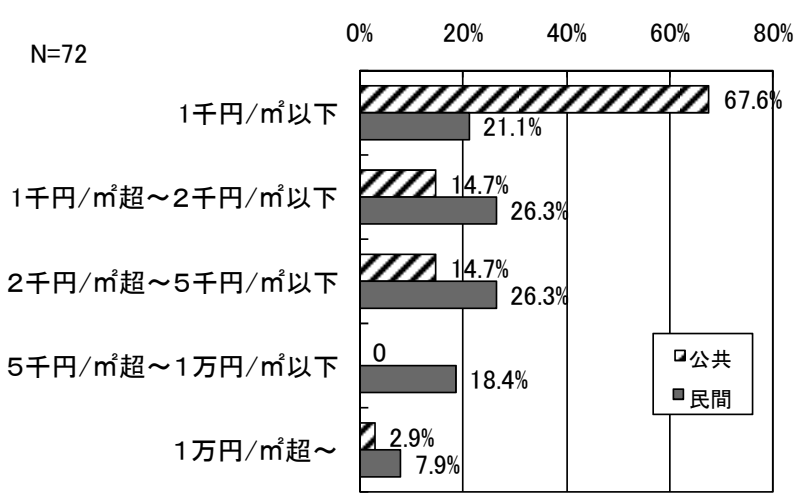

\section{図一8＼cjkstart屋上緑化の維持管理費}

また，公共施設の方が公開されている屋上緑化施設の夜間への 立ち入り制限が多い割合を示したのは，民間施設にはホテルや大 規模商業施設の屋上や大規模な再開発によって公開空地等と一体 的に整備された施設が含まれているのに対して，公共施設には区 役所や博物館，清掃工場等の施設が含まれており，夜間は敷地内 への立ち入りが制限されている場合が多いためと考えられる。こ のことについては，今後実地調査を行う等によりさらに検証を行 うことが必要である。

次に，屋上緑化の施設形態として庭園の占める割合が公共・民 間とも約半数を占めていた。このことから，屋上緑化の目的とし て，ヒートアイランド対策等の環境保全目的はもとより，屋上を 鑑賞や散策等の場として利用が可能な修景的な要素も取り入れた 空間として整備されつつあることを示唆している。また，整備さ れた植栽の形態についてみると，公共施設の場合には，芝生やセ ダム等の比率が民閒施設の場合よりも高くなっているのに対して, 高木・中木の樹木植栽の比率については民間の方が高い傾向とな った。このことは，土層厚 $50 \mathrm{~cm}$ 超，施工費 5 万円 $/ \mathrm{m}^{2}$ 超，維持管 理費 5 千円 $/ \mathrm{m}^{2}$ 超については, いずれも民間と公共の間で顕著な差 が見られたことからも裏付けられた。公開されている面積は，民 間施設の方が少ないが，公開されている民間施設では，百貨店や ホテル等集客性の高い民間施設が含まれていることもあり，日本 庭園等に見られるように樹木の種類も高木から低木まで多様な種 類が使用され，施設内での観賞や散策を目的として公開された緑 化施設が整備されている。今後の低炭素社会の実現等に資する都 市空間を構成していくためには，屋上緑化にも $\mathrm{CO}_{2}$ の吸収・固定 能力の高い高木等の樹木の活用を推進していくことが必要と考え られ，公共施設において積極的な取り組みを図り，普及していく ことも必要と考えられる。

一方，耐荷重量については， m²当たり $300 \mathrm{~kg}$ では公共の方が民 間よりも高い比率を示した。公共施設では公開されている緑化施 設の面積規模も民間施設よりは大きく， m²当たりの整備単価が低 く抑えられ，維持管理の単価も $\mathrm{m}^{2}$ 当たり 1,000 円以下が大半を占 めることから，高木や中木等の植栽された多様な植栽形態は避け られ，芝生類や低木類が主体の植栽形態となっている。これに対 して，民間施設では集客性の高い施設が含まれていることから， 集客効果をより高めるために植栽の構成も高木や中木も植栽され た施設が整備されるとともに，整備水準を維持するために必要と なる相応の維持管理コストも負担していると考えられる。なお, 公共施設と比較して耐荷重量が小さい民間の施設において，高木 等荷重のかかる植栽がより多く見られるが，これは土壌の軽重， 薄層化や薄層土壌に対応した植栽材料の使用等による技術的な対 応 ${ }^{14), 18}$ により実現しているものと推察される。

本研究では，既存の文献等から一定規模以上の屋上緑化施設を 
抽出してアンケート調査を行っており, 調査対象施設も大半が東 京都内であったため, 屋上緑化施設一般の傾向とすることには無 理がある。また，文献等に掲載された屋上緑化施設については， もともと緑化に対応した構造特性を有する建築物が大半を占めて いたことから，比較的優良事例を多く含んでいた。さらに，植栽 状況についても, 主要植栽についてアンケートに記述された結果 に基づいており，植栽構成の実態についても実地調査等で追跡す ることが必要と考えられる。このため, 今後対象範囲やサンプル 数の拡大を図るとともに, 実地調査を行う等により, 調査の精度 を高めさらにデータを蓄積する必要があると考えられる。

屋上緑化施設において, 植栽の種類を高木も植栽されたより多 様性のある空間として構成していくためには，屋上緑化施設を都 市住民の多様な利用に供する緑とオープンスペースの拠点として 計画上の位置づけを明確化しいくことも必要である。また，東京 都のマンション環境性能表示制度 ${ }^{34)}$ に見られるように整備された 緑化施設の質を客観的に評価できる制度を一般化していくことが 技術的課題と考えられる。今後, 低炭素社会の実現, 都市景観の 向上や生物多様性の維持, 防災性の向上をはじめ都市住民の身近 な自然とのふれあい等屋上緑化施設の有するこれらの多面的な機 能に留意し, 整備される緑化施設の公開性と植栽構成の多様性, 維持管理水準の質を高めていくための手立てについて官民連携で 構築していくことが課題と考えられる。

\section{5. まとめ}

屋上緑化の公開と植栽形態, 費用の実態について, 東京都の資 料と既存の文献を元に建築物所有者にアンケート調査を行い，公 共施設と民間施設との間の比較検討を行った。本研究で得られた 主な知見は以下のとおりである。

1）公開されている施設数は, 公共, 民間とも約 6 割の施設が公 開されていたが，公開されている平均緑化面積では, 公共施設 が 4, 824 m²/件となり，民間施設の約 4.6 倍を示した。

2）屋上緑化施設を公開するための必要面積として $1,000 \mathrm{~m}$ `を上 回ることが計画・設計上の目安となることが示唆された。

3）屋上緑化の主な利用形態としては，庭園利用が最も多く，こ のことは屋上をヒートアイランド対策のみならず，観賞や散策 等の利用価值が重視されていることが示唆された。

4）民間施設の方が公共施設よりも高木や中木等の樹木を植栽す る比率が相対的に高く, 施工単価と維持管理単価にもこの傾向 は反映されていた。

謝辞: 本稿は, 平成 19 年度に独立行政法人建築研究所の行った「屋 上緑化アンケート調査業務報告書」のデータを元に, 分析を行っ たものである。また，東京都の緑化完了書のデータについては, 東京都環境局都市地球環境部環境配慮事業課より多大のご協力を いただいた。

\section{補注及び引用文献}

1）関係府省連絡会議：ヒートアイランド対策大綱 : 環境省ホームページ $\langle\mathrm{http}: / /$ www. env. go. jp/press $\rangle$, 2004. 3. 30 参照

2）東京都 (2001)：東京における自然の保護と回復に関する条例第 14 条 $\langle$ http://www2. kankyo. metro. tokyo. jp/sizen/ jorei/joubun/sizenho go_jyourei.htm〉, 2001.4.3 参照

3）東京都環境局（2008）：東京都における屋上等緑化指導実績 〈http://www2. kankyo. metro. tokyo. jp/green/shyukei〉, 2009. 4. 3 参照

4）小高典子・梅干野 晃・田中稲子 (2001) : 都市の屋上緑化 対する一般利用者及び行政担当者の認識に関する調查研究: 日本建築学 会大会学術講演梗概集（関東）：723-724.

5）建設省住宅局市街地建築課 - 屋上開発研究会（1999）: 都市における建
築物等の緑化に関するアンケート調査, $30 \mathrm{pp}$.

6）鹿士由里子・岸本達也（2006）: 東京都区部における屋上緑化の現状 に関する研究：日本建築学会大会学術講演梗概集 (関東), 661-662.

7）佐久間護・興水 肇・原田鎮郎・武藤 浩（2001）：建築物の壁面緑化 に関寸る研究その 1 緑化の目的と緑化手法の現状 : 日本建築学会大会 学術 講演梗概集 F-1 分冊: 681-682.

8）武藤 浩・輿水 肇・原田鎮郎・佐久間 護（2001）：建築物の 壁面緑 化に関する研究その 2 一般人の評価構造に基づく計 画上の課題の抽 出: 日本建築学会大会学術講演梗概集 F-1 分冊, 683-684.

9）鈴木弘孝・小島隆矢・嶋田俊平・野島義照・田代順孝 (2005) : 壁面緑 化に関する技術開発の動向と課題: 日本緑化工学会誌, 31 (2) :247-259.

10) 藤田茂·今井一隆 (2003)：多様な工法・緑化資材を使用した屋上庭園： 造園技術報告 $2, \quad 110-113$

11) 広永勇三・福沢敏・菊池直樹（2003）: 土層軽量化と省労力管理に向け たヤジ繊維土のうによる屋上緑化の検討 : 造園技術報告 2，98-101

12)木野村泰子・下村孝（2008）：オフィスワーカーが休嚊のために訪れる 屋上の現状と屋上緑化の今後のあり方 : ランドスケープ研究，71(5), $27-832$

13)鈴木弘孝・加藤真司 藤田茂・金甫炫 (2009): 屋上緑化施設の公開に関 する実態調査: 日本緑化工学会誌 35(2) 228-231

14)ディテール 151 (2002) : 環境緑化新聞, 152 pp.

15) 建築技術（2002）(株) 建築技術，268 pp.

16) 建築設計資料 85 屋上緑化・壁面緑化 (2002) 建築資料研究社, 208 pp. 17) LANDSCAPE DESIGHN No. 25（2001）: マルモ出版, 158 pp. 18) LANDSCAPE \& GREENERY (2005) : 環境緑化新聞, 178 pp.

19) 日経アーキテクチュア編 (2003) : 実例に学ぶ屋上緑化: 日経BP 社, 189 pp.

20) 日経アーキテクチュア編（2006）：実例に学ぶ屋上緑化 2 : 日経 BP 社, $214 \mathrm{pp}$.

21）日本政策投資銀行（2004）: 都市環境改善の視点から見た建築物緑化の 展望 : 日本政策投資銀行, $74 \mathrm{pp}$.

22)緑化建築年鑑 2005（2005）創樹社, 346 pp.

23)最新の緑化建築技術 (2006) 創樹社, $233 \mathrm{pp}$.

24) 建築物緑化編集委員会 (2005) : 屋上・建築物緑化事典, 産調出版, 398 pp.

25)都市空間を多彩に創造する（2006）講談社，224 pp.

26) 東京都新宿区 (1994）: 都市建築物の緑化手法, 彰国者, 127pp.

27)都市公園 No. 155 （2001）(財)東京都公園協会, 105 pp.

28) 山田宏之 (2001) : 屋上緑化の全てがわかる本, 環境緑化新聞, 166 pp.

29) (財)都市緑化技術開発機構編 (1996) : 特殊空間緑化シリーズ(2)新・緑 空間デザイン技術マニュアル，誠文堂新光社刊， $237 \mathrm{pp}$.

30) (財)都市緑化技術開発機構編（1996）: 特殊空間緑化シリーズ(4)新・緑 空間デザイン技術マニュアル，誠文堂新光社刊，231 pp.

31）13）を元に数值の精查を行い，一部加工修正している。

32)「長寿社会対応住宅設計指針」第 3 条では6 階超の高層住宅にはエレベ ーターを設置するとともに，できる限り 3〜 階の中層住宅等にもエレ ベーターを設けることになっており，高層と中層を分類している。 〈http://www. jaeic. or. jp/hyk/sisin. htm〉, 1995. 6. 23 参照

33)道路緑化技術基淮 ・同解説（1988）：日本道路協会，340pp.

34) 東京都環境局 (2005) : マンション環境性能表示制度の概要〈http:// www. metro. tokyo. jp/INET/OSHIRASE/2005/05/20f5u200. htm〉, 2005. 5. 30 参照 